Rabaska

Revue d'ethnologie de l'Amérique française

\title{
Accusé de non-assistance à patrimoine en danger
}

Volume 17, 2019

URI : https://id.erudit.org/iderudit/1066017ar

DOI : https://doi.org/10.7202/1066017ar

Aller au sommaire du numéro

Éditeur(s)

Société québécoise d'ethnologie

ISSN

1703-7433 (imprimé)

1916-7350 (numérique)

Découvrir la revue

Citer ce document

(2019). Accusé de non-assistance à patrimoine en danger. Rabaska, 17, 249-249.

https://doi.org/10.7202/1066017ar d'utilisation que vous pouvez consulter en ligne.

https://apropos.erudit.org/fr/usagers/politique-dutilisation/ 


\section{Place publique}

\section{Points de vue / livre}

\section{Accusé de non-assistance à patrimoine en danger}

Yves Lacourcière, ingénieur civil de formation, travaille depuis plus de trente ans à faire reconnaître la valeur identitaire du patrimoine bâti et des métiers traditionnels qui lui sont associés. En 1993, il produit une étude socioéconomique, soutenue et cogérée par le ministère de la Culture et des communications du Québec, où il annonçait la mort de ces patrimoines indissociables que sont d'une part la pierre et le bois et d'autre part les connaissances et les tours-de-main de leurs artisans. Selon lui, le Ministère n'a pas cru en ses recommandations puisque rien n'a été modifié depuis ce temps dans les pratiques gouvernementales. En 2018, Yves Lacourcière reprend le flambeau et fait paraître à compte d'auteur un essai polémique qui affirme haut et fort qu'en moins de 50 ans $33 \%$ du bâti ancien a été irrémédiablement détruit tandis que les savoir-faire traditionnels sont sur le point de s'éteindre.

Rabaska a demandé à deux experts de rendre compte de cet ouvrage. Martin Thivierge est le nouveau directeur général du Conseil des métiers d'art du Québec et préside à ce titre les « Rendez-vous Maestria » consacrés à la préservation et à la mise en valeur du patrimoine bâti de même qu'à la transmission des savoir-faire de ses artisans. Paul-Louis Martin a été pour sa part membre de la Commission des biens culturels du Québec de 1978 à 1988, organisme qu'il a présidé à partir de 1983, puis est devenu professeur

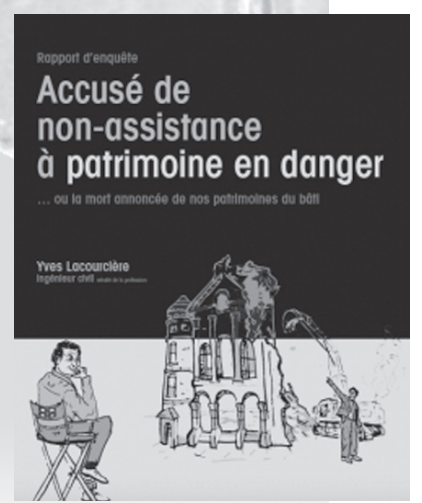

d'histoire de la culture matérielle à l'Université du Québec à Trois-Rivières de 1990 à 2005, année de sa retraite.

LACOURCiĖRe, Yves.

Rapport d'enquête. Accusé de non-assistance à patrimoine en danger... ou la mort annoncée de nos patrimoines du bâti.

Québec, Contrad international, 2018, 299 p. ISBN 978-2-9817400-0-7. 